\title{
Paideusis
}

\section{"Digital Media and Democracy: Tactics in Hard Times " (Megan Boler (Ed.))}

\section{Michelle Stack}

Volume 17, Number 2, 2008

URI: https://id.erudit.org/iderudit/1072435ar

DOI: https://doi.org/10.7202/1072435ar

See table of contents

Publisher(s)

Canadian Philosophy of Education Society

ISSN

0838-4517 (print)

1916-0348 (digital)

Explore this journal

Cite this review

Stack, M. (2008). Review of ["Digital Media and Democracy: Tactics in Hard Times " (Megan Boler (Ed.))]. Paideusis, 17(2), 99-102.

https://doi.org/10.7202/1072435ar

This document is protected by copyright law. Use of the services of Erudit (including reproduction) is subject to its terms and conditions, which can be viewed online.

https://apropos.erudit.org/en/users/policy-on-use/
This article is disseminated and preserved by Érudit.

Érudit is a non-profit inter-university consortium of the Université de Montréal, Université Laval, and the Université du Québec à Montréal. Its mission is to promote and disseminate research.

https://www.erudit.org/en/ 
Review of

\title{
Digital Media and Democracy: Tactics in Hard Times
}

by Megan Boler (Ed.),Cambridge, MA: Massachusetts Institute of Technology Press, 2008

\author{
MICHELLE STACK \\ University of British Columbia, Canada
}

We no longer find ourselves dealing with the mass/individual pair. Individuals have become "dividuals," and masses, samples, data, markets, or "banks (Deleuze, 1992)

...The relationships that reduce us as separate selves to digitally mediated signifiers and that "reproduce" those signifiers as dividuals also provide the potential for resistance against the oppressions resulting from digital re(pro)ducibility (Williams, 2005)

Digital Media and Democracy: Tactics in Hard Times, edited by Megan Boler, points out the dangers of being reduced to "dividuals" as well as potential for disruptions that allow for resistance to oppression.

The strength of this book is that all the authors are looking at digital media through the lens of concepts of social justice, critical theory or post-structuralism, but the book refuses to provide a unified vision of digital media, democracy and dissent. It goes beyond digital resistance as promise versus peril and provides a nuanced understanding of digital dissent. What I especially like is that the book includes both academic researchers as well as work by activists. This type of collaboration is lacking in much work and it is desperately needed. Boler quotes Wark, who remarks that "perhaps theory needs to find a pace and a style that allows it to accompany the event, but without pretending to master it" (Wark, 1994 - cited in Boler, 2008, p. 13). Developing useful theory that assists people in working together to decrease inequality requires a closer relationship and collaboration between academics, journalists, and media activists.

The book analyzes whether the plethora of digital dissent efforts have merely pacified or created alternative discourses that move people to action. I, like many of the authors in the volume, was particularly struck by the strength of Jodi Dean's argument (Chapter Three) that "participation in the mere proliferation of messages is by no means necessarily engaging others in antagonistic, productive, political debate" (274).

I continue to agree with Dean, but I appreciated Brun's counter-arguments that point to the role of consensus and dialogue in democracy. I think perhaps what could enrich this discussion is an examination of different sites and types of political engagement. For example, there are a number of articles in Digital Media and Democracy about projects that aimed to involve people often excluded from media production, particularly women, youth and racialized groups (Renzi (Chapter 2), Schmidt and

(C) Copyright 2008. The author, Michelle Stack, assigns to Paideusis the right of first publication and educational and non-profit institutions a non-exclusive license to use this document for personal use and in courses of instruction provided that the article is used in full and this copyright statement is reproduced. Any other usage is probibited without the express permission of the author. 
Boler (Chapter Nine), Rosas, (Chapter Fourteen). From these articles it appears the focus was not on challenging and debating participants but facilitating their right to making public their opinions and lives. Authors such as Meikle (Chapter Sixteen) also raise issues around tactical media as important forms of "play" that can among other things expand understandings and disrupt notions of identity, power and progress.

Perhaps Nancy Fraser (1997) can help us in thinking through democracy and inclusion. Fraser talks about counter-publics that allow marginalized groups to develop a sense of identity and safety as they strategize change. With this strength they can more powerfully enter more dominant spaces and contest who gets to define problems and solutions. The strategy may require a group to come to a consensus about their strategy. This could be useful to looking at multiple digital and face-to-face spaces that allow for dialogue, consensus and antagonistic debate at different points.

I do agree with Dean (Chapter Three) that when we want to change policies that oppress, to not engage in debate is to allow dominant representations of discourse to remain. As someone who spent many years in politics, I can attest that the language of consensus and consultation abounds, but it is frequently a rhetorical device that is not meant to lessen inequality but to seek consent and buy-in for the status quo, while constantly appearing new and innovative. There are interests at play in framing debate as outdated. The notion of democracy as based on consensus privileges those who are already seen as legitimate sources of power and influence. Instead, we need, like Moeller (Chapter Six), to challenge the rhetoric of democracy. What is so crucial and eloquently stated by activists and academics included in this book, such as McChesney, Goodman and Boler is disrupting the illusion of a democracy based on consensus and instead strategize ways to expand the involvement of people who are often marginalized in political debate through various independent forms of media.

Atton (Chapter Eight) offers an important antidote to critical media studies that frequently fall into the trap of celebration alternative media.

Critical media research that identifies too closely with its objects of study performs a doubledisservice. First, it runs the risk of abandoning its very ethos (the critique of media power). Second, it will fail to provide critical accounts of alternative media that might be useful to alternative media producers. In this rush to praise and support alternative media, critical media research appears reluctant to examine them too closely. (Atton 218)

In his interview with Boler (Chapter Nineteen) Holmes raises issues concerning the lack of large collective involvement of professors and students in challenging oppressive policies which he considers to be of vital importance. Perhaps further examination of the role of academics in the complex web of reproduction of dominant discourses and valorized forms of critique would be productive. In addition, educational institutions play central roles in determining access to the hardware and software that provides opportunities and constraints for digital dissent as well as policies around privacy and surveillance.

Boler and Turpin (Chapter Seventeen) have done rigorous and extensive work on the Daily Show. I also enjoy watching the Daily and am convinced it serves an important role in popularizing alternative discourses to surveillance and war. But, again, I think we need to be careful about how we analyze these programs and their role in dissent. For example, I was recently in New York and went to a lecture by eleven Daily Show writers--all male, all but one appeared to be white. They were asked why there were no women writers. The answer was they had had a couple work with them, and then one writer air quoted that the inventor of the Daily Show was female. A clip that was shown at the lecture had a segment in which John Oliver attends the Democrat Convention and attempt to embarrass a Democratic organizer by leaning into her space in an attempt to kiss her. I fail to see what is political about this. It appears to be sexual harassment rather than useful political engagement.

I do question why in the work I do in video production with youth, it is generally white males who want to do Daily Show take-offs, while many of the girls and racialized minorities want to do 
serious pieces that focus on their feelings of alienation. We need to look at not only who are perceived leaders in the corporate and government sectors but in alternative media and social movements as well. Is it a new form of sexism that involves irony to lighten very serious issues of exclusion?

We do need to develop from previous movements such as the Women's movement that excluded women of color, queer women or women with disabilities, or the Students for a Democratic Society in the 1960s who spoke to sexism but were led by males. The frequent refrain of "Well, we just can't find women to lead or be writers for shows like the Daily" needs to be scrutinized. How do we work to build the power of these alternative discourses while not playing into an "externalizing" of oppression as something that is an issue in corporate media and government but not within academe, progressive social movements and alternative media activism?

Scott's contribution "Tempests of the Blogsphere" (Chapter Eleven) raised questions for me on strategies for talking to those outside of the choir. He warns readers to be careful of enlightenment thinking that celebrates technology as the cure for all problems while masking continued inequalities. He also points to the scarcity of political blog successes versus political blog-flops. Furthermore, Scholz and Deibert's contributions (Chapters Fifteen and Five) both point to the disturbing role of surveillance on the Internet. On the other side Magnan et al. interview with, Hassan Ibrahim (Chapter Twelve) points to the important role bloggers play as one of other sources for Al-Jazeera. But as Statzel (Chapter Eighteen) reminds us, dissent is not always positive. Racist groups abound on the Internet.

All the contributions point to the need to rethink the epistemology that has been central to education based on a model of "justified true belief" (Lanksher, Peters, Knobel, 2000), which has been central to Western education thought for two thousand years. The digital era has changed the construct of knowledge as linguistically based to something that includes text along with sound and image. Knowledge becomes focused on exchange value rather than use value. "Belief, justification and truth need not come near the entire operation. "(Lankshear, Peters, Knobel, 2000, p. 38)

Digital Media and Democracy points to the need for critical media education throughout the formal and informal education programs that provides opportunities to look at various ways that media as well as schools construct legitimate truth and knowledge. Central to this undertaking is an exploration of the contradictions, and opportunities for educators to engage themselves and students in questioning the knowledge claims they make and what forces influenced these claims. From this point students and educators can make choices based on reflection as to whether and how they wish to engage in digital and other forms of dissent.

\section{References}

Fraser, N. (1997). Justice interruptus. New York: Routledge.

Gilles Deleuze, D (1992). Postscript on the societies of control October, Vol. 59. (Winter). pp. 3-7.

Lankshear, C., Peters, M., \& Knobel, M (2000). Information, knowledge and learning: Some issues facing epistemology education in a digital age, The Journal of the Philosophy of Education Society, 34 (1), pp. 17-39.

Wiliams, R (2005) Politics and Self in the Age of Digital Re(pro)ducibility. Fast capitalism. Accessed on December 1, 2008, http://www.uta.edu/huma/agger/fastcapitalism/1_1/williams.html

\section{About the Author}

Michelle Stack is an Assistant Professor in Educational Administration and Leadership, Department of Educational Studies, Faculty of Education, University of British Columbia. Her research interests include: Impact of Media on Policy and Leadership, Media and Patholgizing of Children, Youth and 
Participatory Research, Critical Policy Analysis, Media Education. She can be reached at michelle.stack@ubc.ca 